\title{
Acetylcholine Release from the Rabbit Retina Mediated by Kainate Receptors
}

\author{
David M. Linn, ${ }^{1}$ Christine Blazynski, ${ }^{2}$ Dianna A. Redburn, ${ }^{3}$ and Stephen C. Massey ${ }^{1}$ \\ ${ }^{1}$ Sensory Sciences Center, Graduate School of Biomedical Sciences, University of Texas Health Science Center, \\ Houston, Texas 77030, ${ }^{2}$ Department of Biochemistry and Molecular Biophysics, Washington University School of \\ Medicine, St. Louis, Missouri 63110, and 'Department of Neurobiology and Anatomy, University of Texas Medical School, \\ Houston, Texas 77225
}

\begin{abstract}
The cholinergic amacrine cells of the rabbit retina may be labeled with ${ }^{3} \mathrm{H}$-choline $\left({ }^{3} \mathrm{H}-\mathrm{Ch}\right)$, and the activity of the cholinergic population may be monitored by following the release of ${ }^{3} \mathrm{H}-\mathrm{ACh}$. Glutamate analogs caused massive ACh release, up to 50 times the basal efflux, with the following rank order of potency: $\alpha$-amino-3-hydroxy-5-methyl-4-isoxazolepropionic acid (AMPA) > quisqualate $(Q Q)=$ kainate (KA) $\gg$ NMDA (in magnesium-free medium) $\gg$ glutamate $>$ aspartate. In contrast, the release of ${ }^{3} \mathrm{H}-\mathrm{Ch}$ was unchanged. Submaximal doses of each agonist were used to establish the specifity of glutamate antagonists. Kynurenic acid was selective for $K A \gg Q Q$, and 6, 7-dinitroquinoxaline-2,3-dione (DNQX) was selective for KA $>Q Q \gg$ NMDA. At low doses, which selectively blocked the response to $K A$, both antagonists blocked the light-evoked release of $\mathrm{ACh}$. These results suggest that $A C h$ release may be produced via several glutamate receptors, but the physiological input to the cholinergic amacrine cells is mediated by KA receptors. Because these cells receive direct input from cone bipolar cells, this work supports previous evidence that the bipolar cell transmitter is glutamate.
\end{abstract}

Glutamate is widely regarded as the major excitatory neurotransmitter in the CNS, including the retina. Much like other neurotransmitters, glutamate activates a variety of postsynaptic receptors (Mayer and Westbrook, 1987; Monaghan et al., 1989), which have all been found in the retina (Miller and Slaughter, 1986; Massey, 1990). Four of these receptors, apparently associated with different postsynaptic ion channels, have been classified according to their affinities for the glutamate agonists kainate (KA), quisqualate (QQ), NMDA, and 2-amino-4-phosphonobutyrate (APB; Foster and Fagg, 1984). Very specific NMDA antagonists and relatively selective KA antagonists are available, and by using these experimental tools, we have tried to identify the excitatory input to a well-described population of cholinergic amacrine cells in the retina.

The vertebrate retina is a layered structure, and in the outer retina, photoreceptors release glutamate and make sign-conserving synapses with horizontal cells and OFF bipolar cells via

\footnotetext{
Received Mar. 29, 1990; revised Aug. 30, 1990; accepted Sept. 5, 1990.

This work was supported by National Eye Institute Grant EY-06515 and Texas Higher Education Coordinating Board Grant 1953. We wish to thank Dr. Robert Marc for discussion.

Correspondence should be addressed to Stephen C. Massey, Sensory Sciences Center, UTHSC, 6420 Lamar Fleming Avenue, Houston, TX 77030.

Copyright (c) 1991 Society for Neuroscience $0270-6474 / 91 / 010111-12 \$ 03.00 / 0$
}

KA or QQ receptors (Slaughter and Miller, 1983a,b; Copenhagen and Jahr, 1989). In contrast, the sign-inverting input to ON bipolar cells is mediated by APB receptors (Shiells et al., 1981; Slaughter and Miller, 1981, 1985). In fact, APB is a specific agonist at this site, which underlies the separation of $O N$ and OFF responses throughout the visual system. Although KA, $\mathrm{QQ}$, and APB receptors have been found in the outer retina, NMDA receptors appear to be rare or absent. NMDA and NMDA antagonists have little or no effect on second-order neurons of most species, including the rabbit (Shiells et al., 1981; Lasater and Dowling, 1982; Slaughter and Miller, 1983b; Lasater et al., 1984; Massey and Miller, 1987; O'Dell and Christensen, 1989).

Visual information is transmitted from photoreceptors to the inner retina via $\mathrm{ON}$ and OFF bipolar cells, excitatory neurons that are strongly immunoreactive for glutamate (Ehinger et al., 1988; Marc et al., 1989). In the inner retina, bipolar cells synapse with amacrine and ganglion cells, and at these synapses, glutamate receptors are abundant. However, in contrast to the outer retina, $A P B$ receptors are absent, and most third-order neurons are excited by NMDA as well as KA and QQ (Slaughter and Miller, 1983b; Bloomfield and Dowling, 1985b; Lukasiewicz and McReynolds, 1985; Coleman et al., 1986; Aizenman et al., 1988; Massey and Miller, 1988, 1990; Coleman and Miller, 1989). Consistent with the role of glutamate as the bipolar cell transmitter, the physiological responses of amacrine and ganglion cells are blocked by glutamate antagonists (Slaughter and Miller, 1983c; Coleman et al., 1986; Massey and Miller, 1988).

The cholinergic neurons of the rabbit retina have been identified as amacrine cells and displaced amacrine cells located on either side of the inner plexiform layer in almost equal numbers (Masland and Mills, 1979; Tauchi and Masland, 1984; Vaney, 1984). Also know as starburst amacrine cells on account of their unique morphology (Famiglietti, 1983a), they are narrowly unistratified with a large overlap, so the dendrites of each group form a dense meshwork in the inner plexiform layer (Tauchi and Masland, 1985). Both groups receive direct input from cone bipolar cells (Famiglietti, 1983b; Brandon, 1987). Although other cells with high membrane turnover, such as photoreceptors, also take up choline, the cholinergic amacrine cells are the only ones to synthesize the neurotransmitter ACh (Masland and Mills, 1979).

In response to a flashing stimulus, the cholinergic amacrine cells release ACh (Masland and Livingstone, 1976; Massey and Neal, 1979; Massey and Redburn, 1982; Masland et al., 1984; O'Malley and Masland, 1989). This provides a method to look 
at the inputs to this system based on the premise that physiologically evoked transmitter release reflects the summed activity of the cholinergic population. Previous work has shown that glutamate analogs stimulate $\mathrm{ACh}$ release from the rabbit retina (Cunningham and Neal, 1985), and this is consistent with the release of an excitatory amino acid from bipolar cells. However, Cunningham and Neal (1985) also found that the pharmacology of glutamate receptors associated with $\mathrm{ACh}$ release was substantially different from other systems. They concluded that glutamate and aspartate act at QQ receptors, but that the endogenous transmitter may be an unknown glutamate analog acting at a KA receptor. Most recently, L-homocysteic acid (L$\mathrm{HCA}$ ) has been proposed as a bipolar cell transmitter in the rabbil retina (Neal and Cunningham, 1989).

In the present study, we determined the effective dose for glutamate analogs on $\mathrm{ACh}$ release and then tested equivalent doses of agonist against known glutamate antagonists. Once the pharmacological profile was established, each antagonist was tested against the light-evoked release of $\mathrm{ACh}$. Fortunately, in the last few years, several new glutamate antagonists have been developed with greater potency and specificity. Kynurenic acid (Kyn) and cis-2,3-piperidine dicarboxylic acid (PDA) are general glutamate antagonists that have previously been used in the rabbit and mudpuppy retina (Slaughter and Miller, 1983a,c; Coleman et al., 1986; Massey and Miller, 1987, 1988). Kyn blocks the action of NMDA at the allosteric glycine site (Birch et al., 1988) but also has some selectivity for KA over QQ (Coleman et al., 1986; Perouansky and Grantyn, 1989). The quinoxalinediones 6-cyano-7-nitroquinoxaline-2,3-dione (CNQX) and 6-7-dinitroquinoxaline-2,3-dione (DNQX) are more potent and show selectivity for $\mathrm{KA}$ and $\mathrm{QQ}$ receptors over NMDA receptors (Honoré et al., 1988; Yamada et al., 1989). Using these pharmacological tools, our results suggest that the physiological input to cholinergic amacrine cells is mediated by $\mathrm{KA}$ receptors. This is consistent with previous evidence that suggests that the bipolar cell neurotransmitter is glutamate.

\section{Materials and Methods}

Preparation. The continuous perfusion system for the rabbit eyecup used in these experiments has previously been described in detail (Massey and Redburn, 1982). Briefly, New Zealand white rabbits of either sex $(1.5-2.5 \mathrm{~kg})$ were deeply anesthetized with urethane (loading dose, $1.5 \mathrm{gm} / \mathrm{kg}$, i.p.), and the orbit was infused with Xylocaine (2\%). A tracheal cannula was inserted to ensure a clear airway, and body temperature was maintained at $37^{\circ} \mathrm{C}$ by a thermostatically controlled heated water blanket. A support ring was attached to the eye, and the cornea, lens, and vitreous were removed, leaving an eyecup lined by the retina. The remainder of each experiment was conducted under dim red light.

Cholinergic neurons were labeled for $30 \mathrm{~min}$ with $20 \mu \mathrm{Ci}$ of ${ }^{3} \mathrm{H}$-choline ( ${ }^{3} \mathrm{H}-\mathrm{Ch} ; 80 \mu \mathrm{Ci} / \mathrm{mmol}$; New England Nuclear) that was evaporated to dryness and redissolved in a small volume of choline-free Krebs' solution (Ames and Nesbett, 1981). During the incubation period, the retina was stimulated with $3-\mathrm{Hz}$ flashing light to maximize choline uptake (Masland and Livingstone, 1976). The preparation was then flushed with Krebs' solution before superfusion cannulae, and a temperature probe were lowered into the eyecup. Perfusion solution was pumped (Sage Instruments, $375 \mathrm{~A}$ ) at $1.5 \mathrm{ml} / \mathrm{min}$ through an in-line heater and maintained at $37^{\circ} \mathrm{C}$. Background radioactivity was reduced by washing via the perfusion system for 60-90 min, during which time, the retina was allowed to dark adapt. Subsequently, 1-min fractions were collected directly into vials and prepared for liquid scintillation counting (Packard CA1900) by the addition of $2 \mathrm{ml}$ Pico-Fluor-40 (Packard). Light stimulation was produced by a LED placed close to the eye, which provided a bright photopic flash of $100 \mathrm{msec}$ duration at $3 \mathrm{~Hz}$. Test solutions were applied to the retina in 1-min pulses by switching from control Krebs' to the test solution by means of a 6-way valve. Platinum electrodes were used to record the electroretinogram
(ERG) throughout each experiment; a b-wave amplitude of $100 \mu \mathrm{V}$ was taken to indicate a healthy, functional retina.

Solutions. The composition of the Krebs' bicarbonate medium used throughout these experiments was modified from Ames and Nesbett (1981). It consisted of $\mathrm{NaCl}(118 \mathrm{~mm}), \mathrm{NaHCO}_{3}(25 \mathrm{~mm}), \mathrm{KCl}(4.7$ $\mathrm{mm}$ ), $\mathrm{CaCl}_{2}$ (2.5 mM), $\mathrm{MgSO}_{4}$ (1.2 mM), $\mathrm{KH}_{2} \mathrm{PO}_{4}$ (1.2 mM), glucose (11.1 $\mathrm{mm})$, and an aliquot of previously prepared choline-free amino acid/ vitamin concentrate. The Krebs' solution was freshly prepared and oxygenated with $95 \% \mathrm{O}_{2}$ and $5 \% \mathrm{CO}_{2}$ to $\mathrm{pH} 7.4$. An anticholinesterase, eserine sulfate (Sigma; $30 \mu \mathrm{M}$ ), was present at all times except for the labeling period of $30 \mathrm{~min}$. CNQX and DNQX were obtained from Cambridge Research Biochemicals, Tocris Neuramin, or as a gift from Dr. T. Honoré, whom we thank for collaboration. All other drugs and reagents were obtained from commercial sources.

ACh analysis. To examine the composition of released radioactivity, ${ }^{3} \mathrm{H}$-ACh was separated from ${ }^{3} \mathrm{H}$-choline by a modified enzymatic method (Shea and Aprison, 1973; Johnson and Pilar, 1980). Each sample was acidified with $\mathrm{HCl}$ in the collection vial to stabilize $\mathrm{ACh}$, and then choline was phosphorylated with a choline kinase solution. ACh was complexed by the addition of tetraphenylboron, and a toluene-based fluor was added to the vial, forming a 2-phase system. Most of the ACh $(90 \%)$ was extracted into the organic phase and counted, but the choline phosphate remained in the aqueous phase and was not counted. A correction was applied for $\mathrm{ACh}$ not extracted, and the crossover of choline from the aqueous stage to the organic phase $(1-2 \%)$ was estimated by adding a known amount of ${ }^{14} \mathrm{C}$-choline.

Data analysis. Data from the counter in the form of DPMs were plotted as release curves versus the fraction number. There are 2 effects that distort the results when handled this way: (1) The release curve is exponential, so, even after a prolonged wash, the baseline declines steadily throughout the experiment. Therefore, responses were quantified relative to the background by dividing the peak-evoked release by the basal efflux, taken as the average baseline $5 \mathrm{~min}$ before drug application. For a repeated drug dose, this ratio remained relatively constant throughout an experiment. (2) The depletion of a finite pool of labeled transmitter leads to smaller responses later in the experiment. This is especially true with glutamate agonists that cause massive ACh release. Therefore, a minimum number of agonist controls were performed, usually at the end of an experiment, and test doses were always compared with a nearby control.

Semilog dose-response curves were constructed by combining data from different experiments. Peak : base ratios for each experiment were normalized to the maximum response for a saturating dose, taken as 1 . Agonist dose-response curves were derived from the equation $V / V_{\max }$ $=[\text { agonist }]^{n} /\left(\mathrm{ED}_{50}{ }^{n}+[\text { agonist }]^{n}\right)$, and antagonist-blockade curves were fitted to the equation $V / V_{\max }=$ [antagonist ${ }^{n /}\left(\mathrm{IC}_{50}{ }^{n}+\right.$ [antagonist] $\left.{ }^{n}\right)$, where $V$ is the response, $V_{\max }$ is the maximum response normalized to $1, \mathrm{ED}_{s 0}$ is the dose of agonist producing half of the maximal response, $\mathrm{IC}_{50}$ is the dose of antagonist reducing the response by half, and $n$ is the Hill coefficient. No significance is attached to the Hill coefficients, which ranged from 2 to 3 , as might be expected for a nonlinear system such as transmitter release. We used ASYSTANT + (Macmillan Software Co., 1986) for least-squares nonlinear curve fitting and the $E D_{50}$ and $\mathrm{IC}_{50}$ calculations.

\section{Results}

\section{Glutamate agonists}

After 60-90 min of perfusion, to reduce the background radioactivity to a steady level, the retina was stimulated with light to ensure that physiological ACh release could be obtained. The preparation was taken as functional if 2 comparable peaks of at least twice the basal efflux were obtained in response to 4-min periods of flashing light at $3 \mathrm{~Hz}$.

The first goal of these experiments was to establish the effective range for each glutamate analog. To minimize the wellknown excitotoxic effects of these compounds, increasing doses were applied briefly for periods of $1 \mathrm{~min}$ until saturation was obtained at approximately 25-30 times the basal efflux. $\alpha$-Amino-3-hydroxy-5-methyl-4-isoxazolepropionic acid (AMPA), QQ, and $\mathrm{KA}$ (Fig. 1) were the most potent ACh-releasing compounds with threshold doses of 1,2 , and $5 \mu \mathrm{M}$ and $\mathrm{ED}_{50} \mathrm{~s}$ of $6.2,10.3$, 


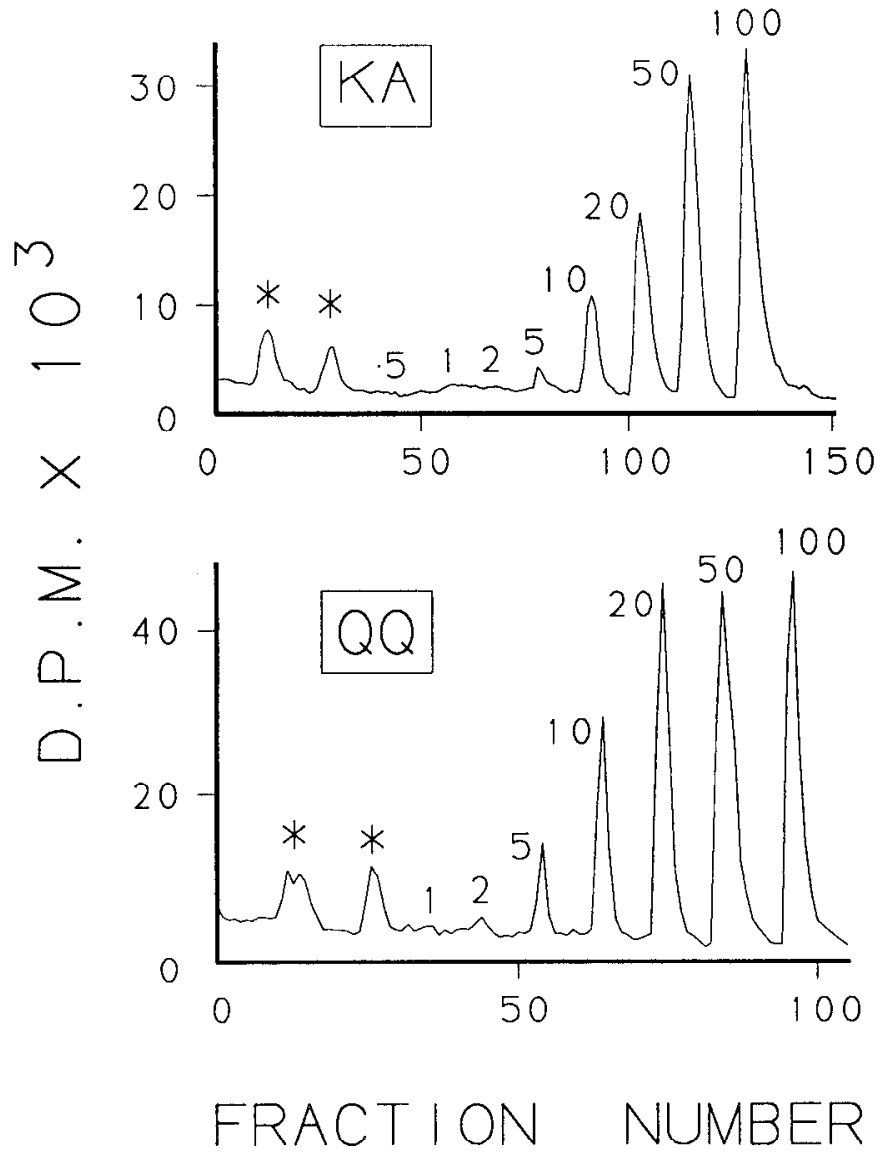

Figure 1. Release of ACh from rabbit retina in response to increasing series of KA (top) or QQ (bottom) concentrations. In this and all other figures, release data in DPMs were plotted against the fraction number. One-minute fractions were collected, and glutamate analogs were applied for $1 \mathrm{~min}$. The numbers indicate the concentration of agonist $(\mu \mathrm{M})$, and asterisks indicate light stimulation at $3 \mathrm{~Hz}$ for $4 \mathrm{~min}$. and $12.4 \mu \mathrm{M}$, respectively (Fig. 2). In normal magnesium (1.2 $\mathrm{mM}$ ), the release of $\mathrm{ACh}$ in response to perfusion with NMDA was completely blocked (see also Linn and Massey, 1991). However, in magnesium-free medium, NMDA was a moderately potent agonist, with a threshold of $50 \mu \mathrm{M}$ and an $\mathrm{ED}_{50}$ of 112 $\mu \mathrm{M}$.

The endogenous amino acids glutamate and aspartate were much less potent, with threshold doses of $2 \mathrm{~mm}$ and $\mathrm{ED}_{50} \mathrm{~s}$ of $5.0 \mathrm{~mm}$ and $5.8 \mathrm{~mm}$, respectively. In addition, glutamate and aspartate consistently released less $\mathrm{ACh}$ at saturation (maximum, 12-15 times the basal efflux) than the glutamate analogs described above. Two other putative transmitters were tested for their effects on $\mathrm{ACh}$ release: $N$-acetylaspartylglutamate (NAAG) had no effect up to a concentration of $20 \mathrm{~mm}$ with or without magnesium. L-HCA was a weak NMDA agonist $\left(\mathrm{ED}_{50}\right.$, approximately $300 \mu \mathrm{M}$ ) because it was most effective in magnesium-free medium. In normal medium, L-HCA produced a smaller response, which suggests a non-NMDA component.

\section{ACh analysis}

Previous work has shown that ACh accounts for essentially all the radioactivity released from the retina in response to light (Masland and Livingstone, 1976; Massey and Neal, 1979; Massey and Redburn, 1982). Because the release of radioactivity by glutamate analogs was so large, we wondered if choline or other labeled metabolites were released, perhaps by cell lysis. However, the analysis shown in Figure 3 shows that more than $90 \%$ of the radioactivity released by $K A, Q Q$, and NMDA could be identified as ${ }^{3} \mathrm{H}-\mathrm{ACh}$. The release of ${ }^{3} \mathrm{H}-\mathrm{Ch}$ was essentially unchanged by light or perfusion with glutamate analogs. Thercforc, in the following experiments, we have taken increments in the release of total radioactivity to indicate the release of $\mathrm{ACh}$ from cholinergic amacrine cells. Approximately half the basal efflux is accounted for by ${ }^{3} \mathrm{H}-\mathrm{Ch}$, so the real peak: base ratio for ${ }^{3} \mathrm{H}-$ $\mathrm{ACh}$ release should be doubled. For example, in Figure 3, 15 $\mu \mathrm{M}$ KA caused a 17-fold increase in the release of total radio-

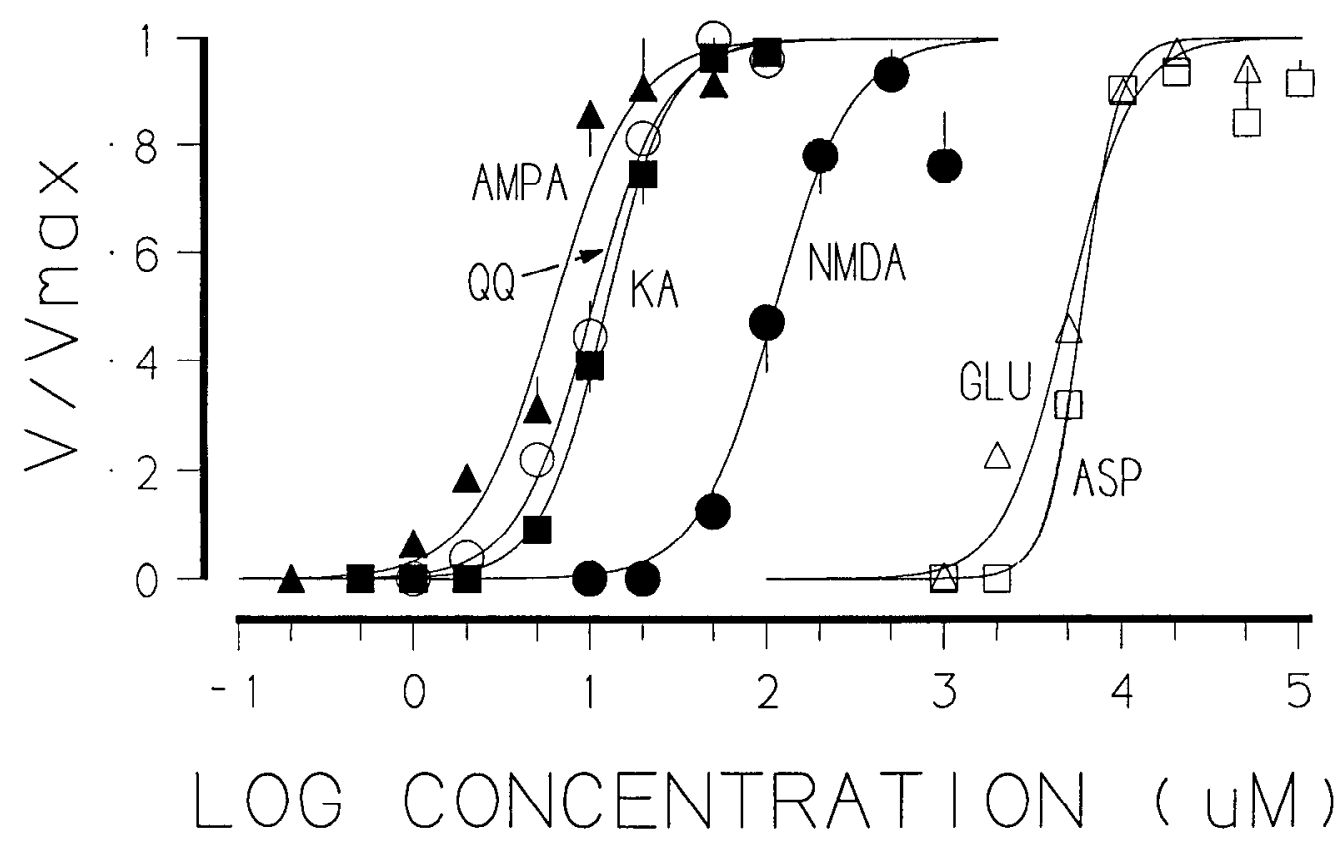

Figure 2. Semilog dose-response curves for glutamate agonists on release of ACh from rabbit retina. $V_{\max }$ for AMPA, QQ, KA, and NMDA was a peak : base ratio of 25-30, and for glutamate and aspartate, 12-15. Vertical hars indicate SEM; where not shown, they are smaller than the symbol. The NMDA curve was derived in magnesium-free medium. $\mathrm{ED}_{50} \mathrm{~s}$ : AMPA, 6.2 $\mu \mathrm{M} ; \mathrm{QQ}, 10.3 \mu \mathrm{M} ; \mathrm{KA}, 12.4 \mu \mathrm{M} ; \mathrm{NMDA}$, $112 \mu \mathrm{M}$; glutamate, $5.0 \mathrm{mM}$; aspartate, $5.8 \mathrm{~mm}$. KA was just significantly different than QQ $\left(\chi^{2}=4.11, \mathrm{df}=1, p<\right.$ $0.05)$. KA and $Q Q$ were both significantly different than AMPA $\left(\chi^{2}=11.43\right.$, df $=1, p<0.01 ; \chi^{2}=8.53, \mathrm{df}=1, p$ $<0.01)$. Glutamate and aspartate were not significantly different. 


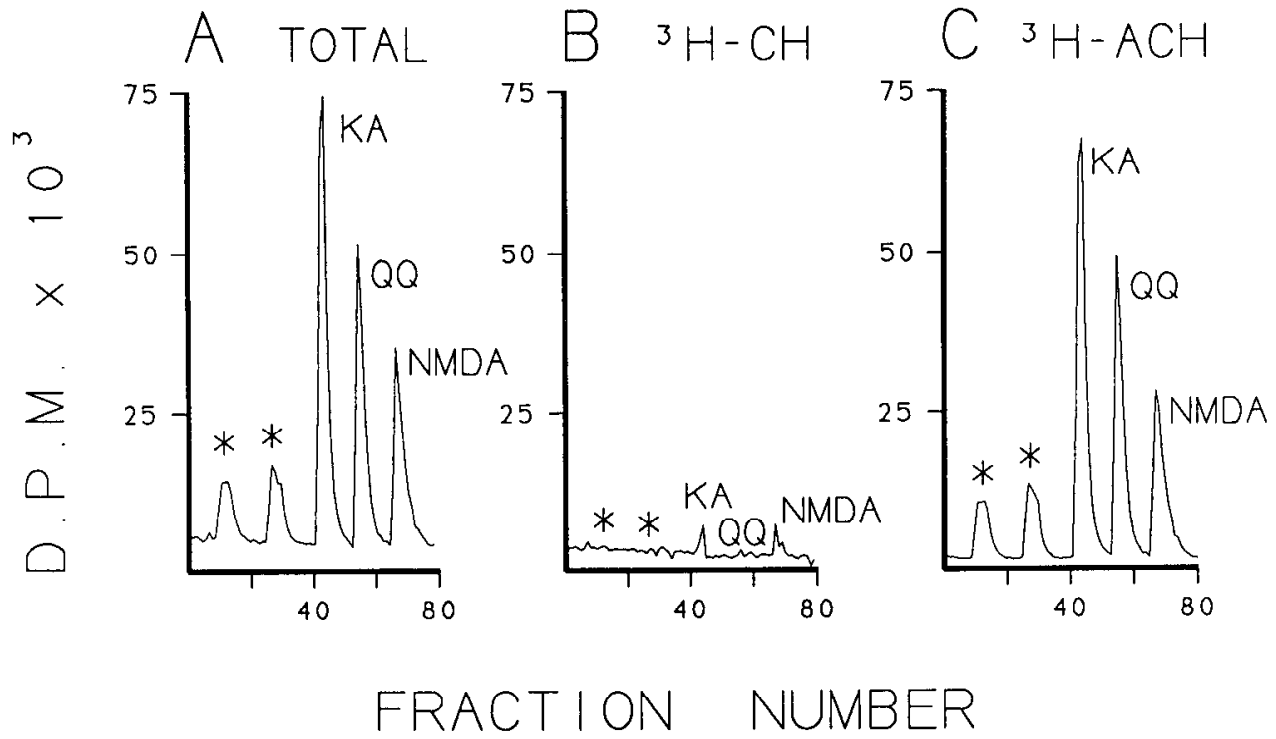

Figure 3. ACh accounts for all radioactivity released from rabbit retina in responsc to glutamate agonists. Half of each sample was counted normally, and $\mathrm{ACh}$ was extracted from the remainder and counted as described in Materials and Methods. This experiment was conducted in magnesium-free medium to promote a response to NMDA. $A$, Total radioactivity released in response to light stimulation (asterisks; 4 min, $3 \mathrm{~Hz}$ ) and KA $(15 \mu \mathrm{M})$, QQ $(15 \mu \mathrm{M})$, and NMDA $(300 \mu \mathrm{M})$, all applied for $1 \mathrm{~min}$. Although the doses of glutamate agonists are roughly equivalent, it is quite normal for the peak size to decrease through the experiment. This probably reflects the depletion of a finite transmitter pool. $B$, Choline released in response to the same stimuli as in $A$. This curve was obtained by subtracting $A C h$ from the total counts (i.e., $A-C$ ). $C$, The release of $\mathrm{ACh}$ in response to light stimulation and glutamate agonists. By measuring the area under each peak, we showed that ACh accounts for more than $90 \%$ of the stimulus-evoked release, but the release of choline was almost unchanged. This indicates that the source of the release is from cholinergic amacrine cells.
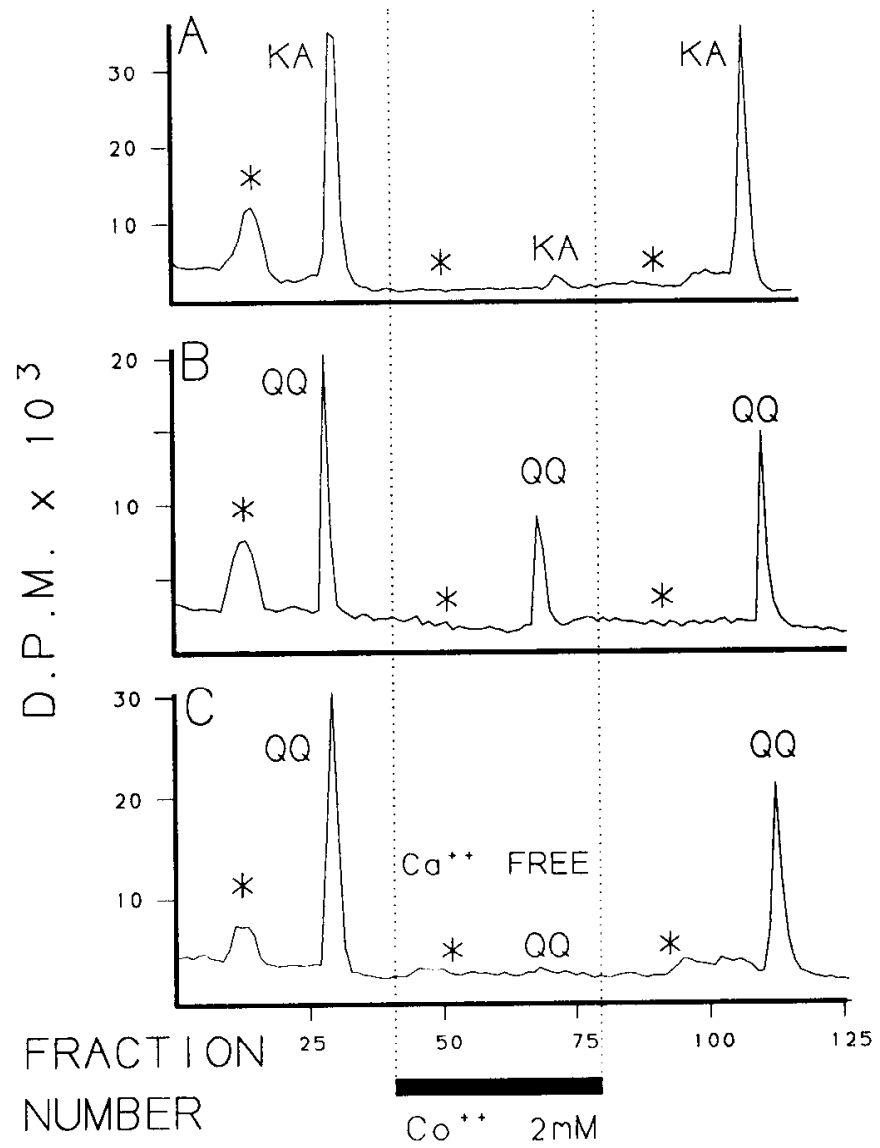

activity. Perfusate analysis shows this actually represents a $39-$ fold increase in the release of ${ }^{3} \mathrm{H}-\mathrm{ACh}$.

\section{Calcium-dependent release}

The light-evoked release of ACh from the rabbit retina is calcium dependent (Masland and Livingstone, 1976; Massey and Neal, 1979; Massey and Redburn, 1982). Therefore, if the ACh released by glutamate analogs originates from the same pool, it should also be calcium dependent. Experiments conducted in 0 calcium and $20 \mathrm{~mm} \mathrm{Mg}{ }^{2+}$ resulted in the complete blockade of light- and KA-evoked release of ACh. However, QQ and, to a lesser extent, AMPA were still able to stimulate ACh release (data not shown).

We repeated these experiments using $2 \mathrm{~mm}$ cobalt, which is much more effective than magnesium and also had a differential effect on KA and QQ responses. In normal calcium, $2 \mathrm{~mm}$ cobalt blocked the KA evoked release of ACh by $83.6 \pm 3.1 \%$ (mean $\pm \mathrm{SEM} ; n=5$; Fig. $4 A$ ), but the equivalent QQ response was only reduced by $36.7 \pm 14.5 \%$ (mean \pm SEM; $n=5$; Fig. $4 B$ ).

Figure 4. KA and QQ are differentially dependent on calcium. This figure shows 3 separate experiments run on the same time scale. Perfusion with $2 \mathrm{~mm}$ cobalt is indicated by the bar and dotted lines for all 3 panels. Asterisks indicate light stimulation at $3 \mathrm{~Hz}$ for $4 \mathrm{~min}$. $A$, The KA- (15 $\mu \mathrm{M})$ evoked release of ACh was reversibly blocked by cobalt. $B$, The effect of QQ (15 $\mu \mathrm{M})$ was reduced by cobalt, but not abolished. $C$, When calcium was removed as well as perfusion with cobalt, the QQ-evoked release of ACh was abolished. These results show that the stimulated release of $\mathrm{ACh}$ is calcium dependent, indicating a neuronal source. However, KA and QQ responses are differentially dependent on calcium, suggesting that 2 distinct receptors are present. 


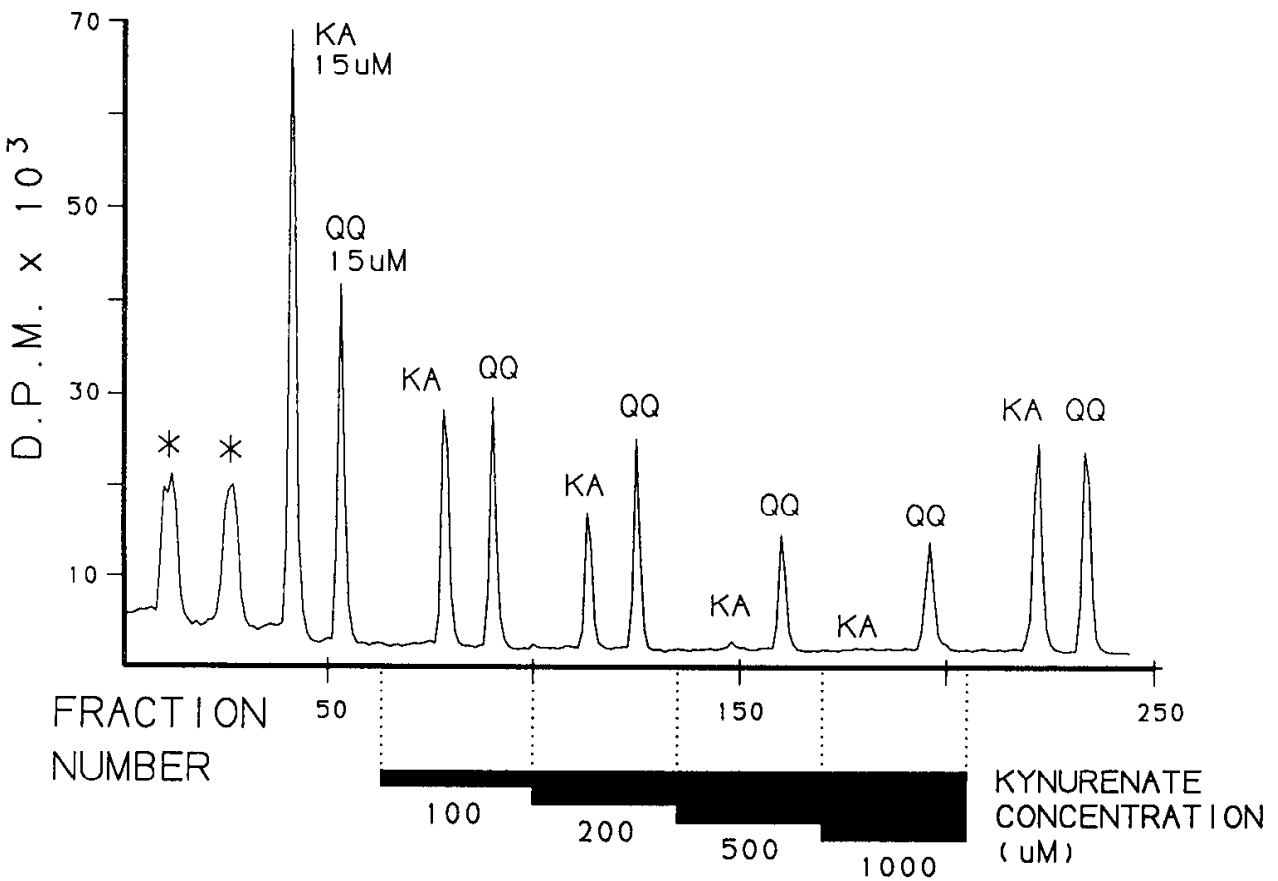

Figure 5. Dose and specificity of Kyn versus KA- and QQ-evoked release of ACh. Equivalent submaximal doses of $\mathrm{KA}$ and QQ were applied for $1 \mathrm{~min}$ in paired stimuli against an increasing staircase of Kyn, shown by the bars and dotted lines. The first KA control peak was unusually large, followed by a sharp drop in the baseline, often seen with the first major peak, but the peak: base ratios for the $\mathrm{KA}$ and $\mathrm{QQ}$ controls were almost the same (15.2 and 14.6, respectively). By $500 \mu \mathrm{M} \mathrm{Kyn}$, only a trace of the KA peak remained, and by $1 \mathrm{~mm}$ Kyn, the KA response was abolished but the peak : base ratio for $\mathrm{QQ}$ was 7 , approximately half the control response. To compensate for the normal rundown in this long experiment, it is important to compare the last peaks in Kyn to the final controls. After washing out the Kyn, KA and QQ elicited similar control responses (peak: base ratios, 14.0 and 13.8 , respectively). This experiment shows that Kyn can be used to separate $\mathrm{KA}$ and $\mathrm{QQ}$ responses in the rabbit retina.
The QQ-evoked release of ACh was blocked by cobalt when calcium was omitted $(72.2 \pm 8.5 \%$, mean $\pm \mathrm{SEM} ; n=6$; Fig. $4 C$ ). Thus, the release of $\mathrm{ACh}$ by glutamate analogs appears to be calcium dependent, consistent with release from a neuronal source. However, these results demonstrate that $\mathrm{KA}$ and $\mathrm{QQ}$ responses can be separated in this preparation, suggesting the possibility of 2 distinct receptors. The profile of the light-evoked release of $\mathrm{ACh}$ most closely resembles that of $\mathrm{KA}$.

\section{Antagonists}

PDA was the first general glutamate antagonist available. As previously reported (Cunningham and Neal, 1985), PDA (5 mM) reversibly blocked the light-evoked and KA-evoked release of $\mathrm{ACh}$ from the rabbit retina. Because more potent and specific antagonists are now available, we did not test PDA against other glutamate analogs.

\section{Kynurenic acid}

Kyn is another general glutamate antagonist that is more potent than PDA and has previously been used in the retina (Coleman ct al., 1986; Massey and Miller, 1987, 1988). To obtain maximum specificity from the available glutamate antagonists, we tried to identify the optimal concentration for each one. Therefore, we tested equivalent submaximal doses of glutamate agonists against an increasing staircase of antagonist concentrations. Figure 5 shows a typical experiment testing Kyn against KA- and QQ-evoked release of ACh. The first 2 peaks were produced by light stimulation to show that the preparation was functional, and then control peaks were obtained in response to perfusion for $1 \mathrm{~min}$ with equivalent doses of $\mathrm{KA}(15 \mu \mathrm{M})$ and QQ $(15 \mu \mathrm{M})$. Increasing steps of Kyn decreased the KA-evoked release of $\mathrm{ACh}$ relative to the $\mathrm{QQ}$ response until, at $1 \mathrm{mM} \mathrm{Kyn}$, the $\mathrm{KA}$ response was abolished but the QQ response was only reduced by half. After washout, full recovery was obtained, and the final KA and QQ peaks were almost identical. This experiment shows that $\mathrm{Kyn}$ is a reversible $\mathrm{KA}$ antagonist and suggests that Kyn may be used to separate KA and QQ responses.
From experiments such as this, data were gathered to produce the antagonist curves for Kyn shown in Figure 6. Kyn was tested against equipotent and submaximal doses of each glutamate analog, KA (15 $\mu \mathrm{M})$, QQ $(15 \mu \mathrm{M})$, and AMPA $(8 \mu \mathrm{M})$. The QQ and AMPA curves were similar, but $\mathrm{KA}$ was much more sensitive to Kyn. The following $\mathrm{IC}_{50}$ values for Kyn were derived: versus KA, $142 \mu \mathrm{M}$; versus AMPA, $761 \mu \mathrm{M}$; versus QQ, $1.4 \mathrm{mM}$. Thus, the KA and QQ curves were separated by $1 \log$ unit, and $1 \mathrm{mM}$ Kyn may be used to differentiate between them.

Kyn blocked the light-evoked release of $\mathrm{ACh}$ and the $\mathrm{KA}$ response over the same range, from threshold at $100 \mu \mathrm{M}$ to a complete block at $1 \mathrm{mM}$. A self-contained experiment is shown in Figure 7. In the first half of this experiment, Kyn (1 mM) reversibly abolished the light-evoked release of $\mathrm{ACh}$ and causcd a $50 \%$ drop in the basal efflux attributable to the block of spontaneous ACh release. This implies that both the light-evoked release and the spontaneous release are synaptically driven. In the second half, the pharmacological specificity of Kyn was tested against equivalent, submaximal doses of glutamate agonists. Kyn (1 mM) abolished the KA (15 $\mu \mathrm{M})$ response, but the responses to QQ $(15 \mu \mathrm{M})$ and AMPA $(8 \mu \mathrm{M})$ were only reduced by $30 \%$ and $70 \%$, respectively. After washout, similar peaks were obtained for KA, QQ, and AMPA. This experiment shows that Kyn reversibly blocks the light-evoked release of $\mathrm{ACh}$, at a dose that selectively blocks the KA-evoked release of ACh.

\section{Quinoxalinediones}

The quinoxalinediones DNQX and CNQX have been reported as "non-NMDA" antagonists in several systems. Our goal was to characterize the pharmacological profile of these compounds in the rabbit retina so they could be used to distinguish between different glutamate receptors. We obtained similar results with either compound, but DNQX was used in most experiments because the 10-mM stock solution appeared to be more stable.

Figure 8 shows an experiment designed to test equivalent doses of NMDA and KA against an increasing staircase of DNQX concentrations. After the initial light-evoked peaks to confirm 
Figure 6. Semilog dose-response curves for KA, QQ, and AMPA versus Kyn. The data were derived from experiments such as that shown in Figure were tested against fixed submaximal doses of KA (15 $\mu \mathrm{M}), \mathrm{QQ}(15 \mu \mathrm{M})$, and SEM; where not shown, they are smaller than the symbol. The KA and QQ curves are separated by 1 log unit, indicating that Kyn is a relatively selective KA antagonist. From these curves, we chose a concentration of $1 \mathrm{~mm}$ as a working dose for Kyn. At this concentration, KA responses were eliminated, but QQ and AMPA responses were only reduced by half. 5 , where increasing doses of antagonist AMPA $(8 \mu \mathrm{M})$. Vertical bars indicate

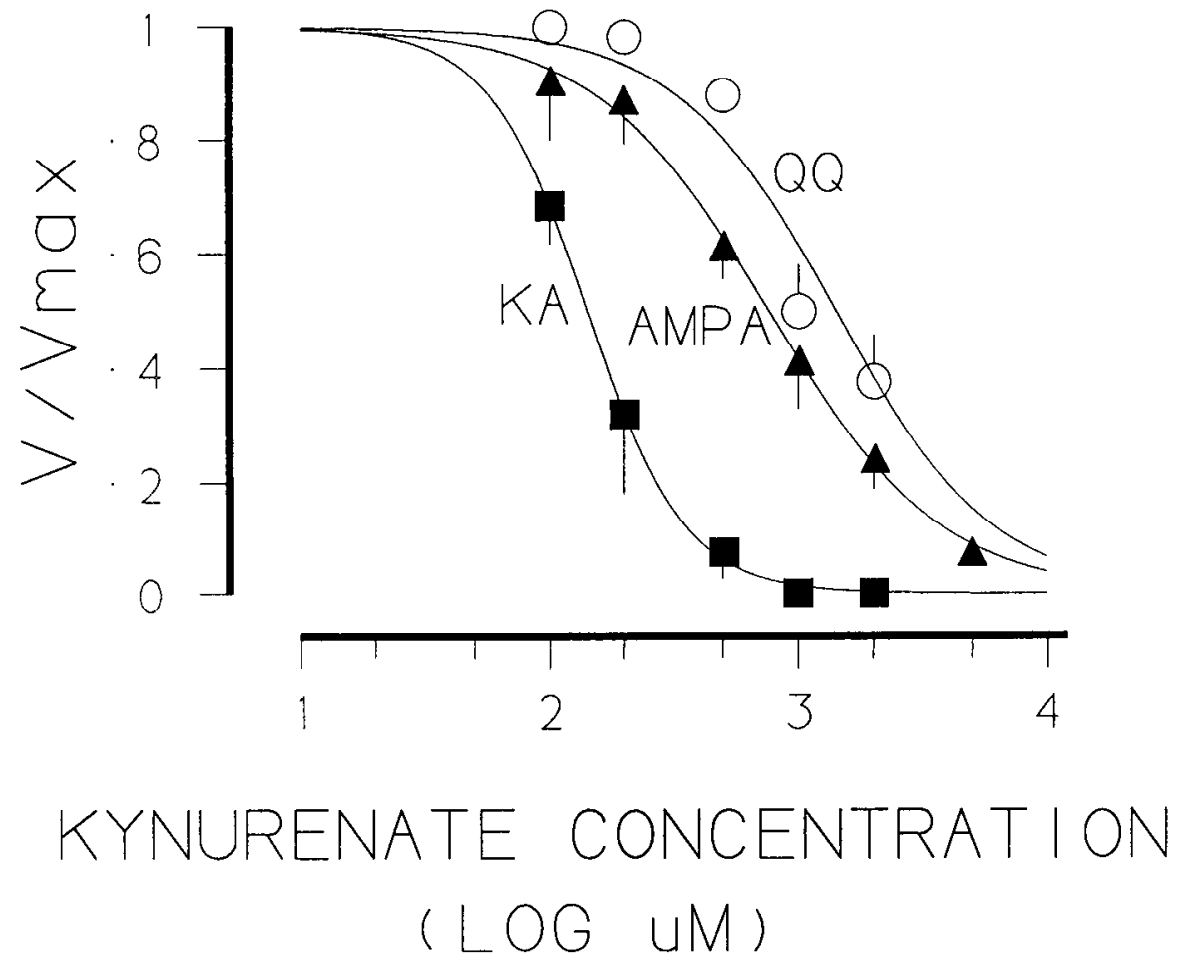

retinal viability, control peaks of $\mathrm{ACh}$ release were obtained with submaximal doses of NMDA $(300 \mu \mathrm{M})$ and KA $(15 \mu \mathrm{M})$. As the concentration of DNQX was increased, the KA-evoked release of $\mathrm{ACh}$ was selectively reduced until, at $5 \mu \mathrm{M} \mathrm{DNQX}$, it was completely abolished, though NMDA still evoked a 15fold increase over the base release. After washout, the final control responses to KA and NMDA were almost the same size. This experiment indicates that low concentrations of DNQX selectively blocked the KA- but not the NMDA-evoked release of $\mathrm{ACh}$.

From a series of experiments like this, DNQX was tested against submaximal doses of $\mathrm{KA}(15 \mu \mathrm{M})$, QQ (15 $\mu \mathrm{M})$, AMPA $(8 \mu \mathrm{M})$, and NMDA (300 $\mu \mathrm{M})$. Then, the data were normalized, and the antagonist curves in Figure 9 were derived, yielding the following $\mathrm{IC}_{50}$ values for DNQX: versus $\mathrm{KA}, 1.2 \mu \mathrm{M}$; versus $\mathrm{QQ}, 2.3 \mu \mathrm{M}$; versus AMPA, $4.0 \mu \mathrm{M}$; versus NMDA, $30.6 \mu \mathrm{M}$.
Figure 7. Kyn: effect on light-evoked release of $\mathrm{ACh}$ and pharmacological specificity. In the first half of this experiment, Kyn ( $1 \mathrm{~mm}$ indicated by the solid bar and dotted lines) was tested against the light-evoked release of $\mathrm{ACh}$ (asterisks). The mean peak: base ratio for the first pair of light peaks was 3.4, and 3.6 for the second control pair. In between, Kyn caused a 50\% drop in the basal efflux, which probably represents the blockade of spontaneous ACh release superimposed on the release of $\mathrm{Ch}$. The light-evoked release of $\mathrm{ACh}$ was completely abolished by $1 \mathrm{~mm} \mathrm{Kyn.} \mathrm{In}$ the second half of this experiment, Kyn blocked the KA $(15 \mu \mathrm{M})$ response, but QQ $(15 \mu \mathrm{M})$ and AMPA $(8 \mu \mathrm{M})$ caused an 8.3- and 3.7-fold increase, respectively. After washout, KA, QQ, and AMPA elicited similar control responses and peak: base ratios of 9.6 , 11.8 , and 12.2 , respectively. Comparing the peaks in Kyn to the controls indicates that $\mathrm{KA}, \mathrm{QQ}$, and AMPA were inhibited by $100 \%, 30 \%$, and $70 \%$, respectively. These results show that Kyn reversibly blocked the light-evoked release of $\mathrm{ACh}$, and in the same experiment, Kyn was shown to be a relatively selective $\mathrm{KA}$ antagonist.

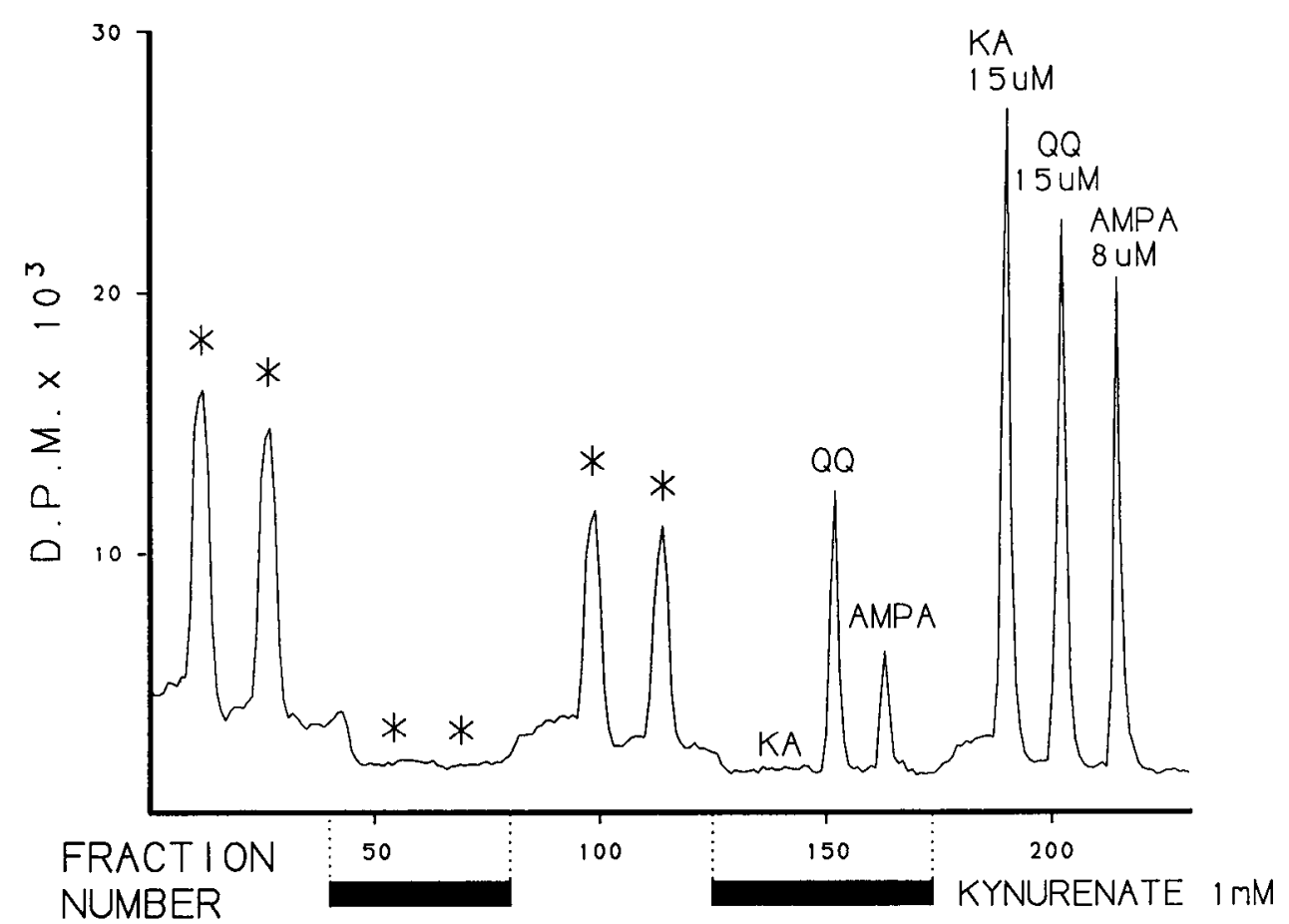




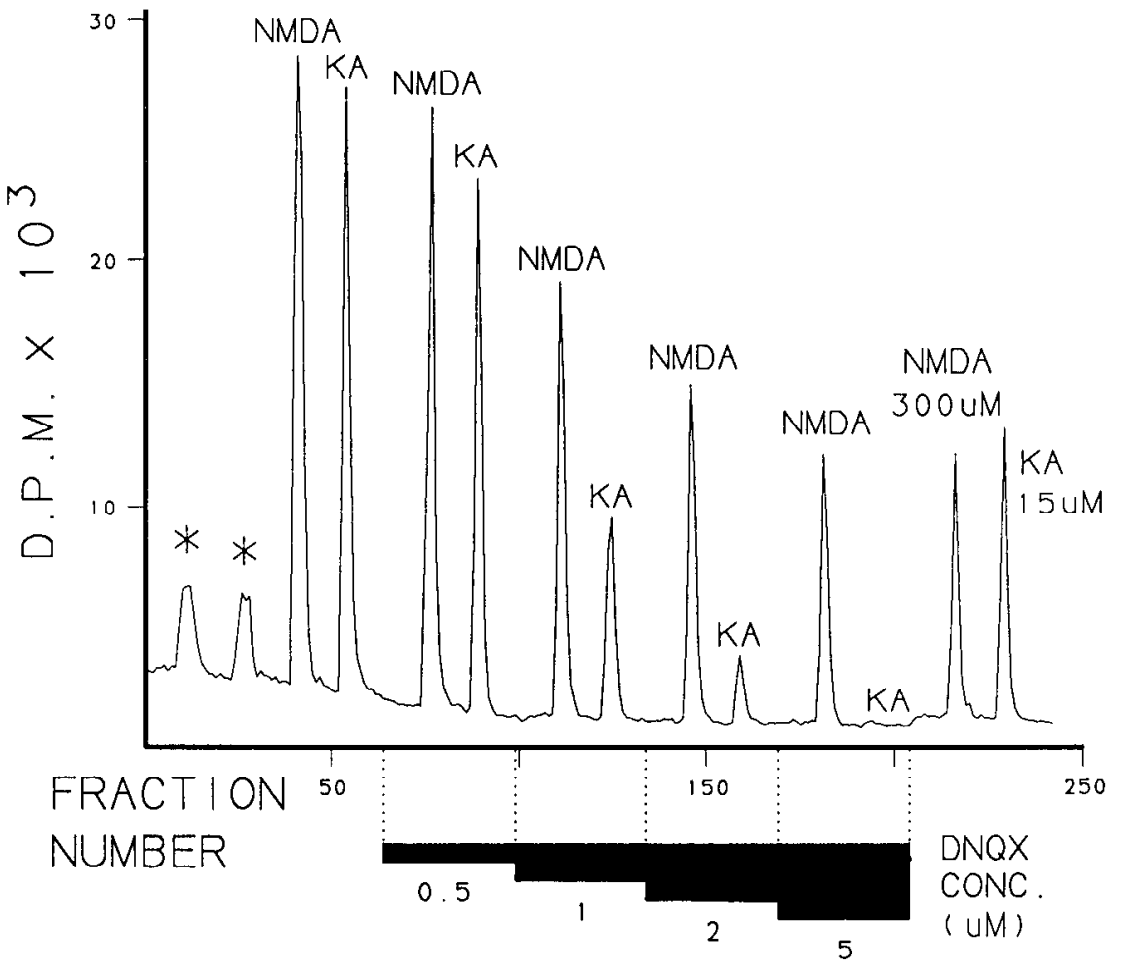

Figure 8. Dose and specificity of DNQX versus KA and NMDA. Submaximal doses of NMDA $(300 \mu \mathrm{M})$ and $\mathrm{KA}(15 \mu \mathrm{M})$ were applied for $1 \mathrm{~min}$ in paired stimuli against an increasing staircase of DNQX shown by the solid bars and dotted lines. This experiment was conducted in magnesium-free medium to promote NMDA responses. The peak: base ratio for the first NMDA response was 11.4, and for the first KA response, 12.2. Starting at $1 \mu \mathrm{M}$ DNQX, the KA-evoked release of $A C h$ was selectively reduced until, at $5 \mu \mathrm{M}$ DNQX, the $\mathrm{KA}$ response was abolished, but NMDA still produced a response with a peak : base ratio of 12.4 . It is important to compare the last 2 responses in DNQX with the final controls, which gave similar responses for NMDA and KA (peak: base ratios, 10.0 and 12.1 , respectively). This experiment shows that $5 \mu \mathrm{M}$ DNQX is a selective KA antagonist in the rabbit retina.
These results indicate that DNQX is over $100 \times$ more potent than Kyn as a KA antagonist. The NMDA curve was separated from the KA curve by more than $1 \log$ unit. Therefore, at doses less than $10 \mu \mathrm{M}$, DNQX can easily be used to differentiate between KA and NMDA, but at concentrations greater than 100 $\mu \mathrm{M}$, NMDA responses were also blocked. The differential between KA and QQ (or AMPA) was less, but DNQX preferentially blocked KA responses; at $3 \mu \mathrm{M}$ DNQX, the KA-evoked release of ACh was blocked by $95 \%$, but the QQ and AMPA responses were only reduced by $60 \%$ and $40 \%$, respectively. We also tested DNQX against the glutamate-evoked release of ACh. However, in 7 experiments, DNQX $(5-20 \mu \mathrm{M})$ consistently failed to block the response to $5 \mathrm{~mm}$ glutamate.

To determine the type of antagonism, we tested a fixed dose of DNQX (10 $\mu \mathrm{M})$ against increasing concentrations of KA. DNQX $(10 \mu \mathrm{M})$ caused a parallel shift of almost 1 log unit in the KA dose-response curve (Fig. 10). Importantly, raising the dose of KA overcame the DNQX blockade, and the same maximum response was obtained with $400 \mu \mathrm{M} \mathrm{KA}$. Although the data in this figure were normalized to 1 , the maximum peak: base ratios underlying these numbers were also the same (50 $\mu \mathrm{M} \mathrm{KA}, 23.2, n=9 ; 400 \mu \mathrm{M} \mathrm{KA}$ in DNQX, 23.0, $n=2$ ). A parallel shift of the dose-response curve reaching the same $V_{\max }$ is the classic result if both compounds are competing for the same site. Therefore, we concluded that DNQX was a potent and competitive $\mathrm{KA}$ antagonist.

Once we had established the correct dose, we tested DNQX against the light-evoked release of $\mathrm{ACh}$. The threshold dose for DNQX versus light was $1 \mu \mathrm{M}$, and a complete block was obtained at 3-5 $\mu \mathrm{M}$. This coincides with the effective range for DNQX versus KA. Figure 11 illustrates a self-contained experiment that may be functionally divided into 2 parts. The

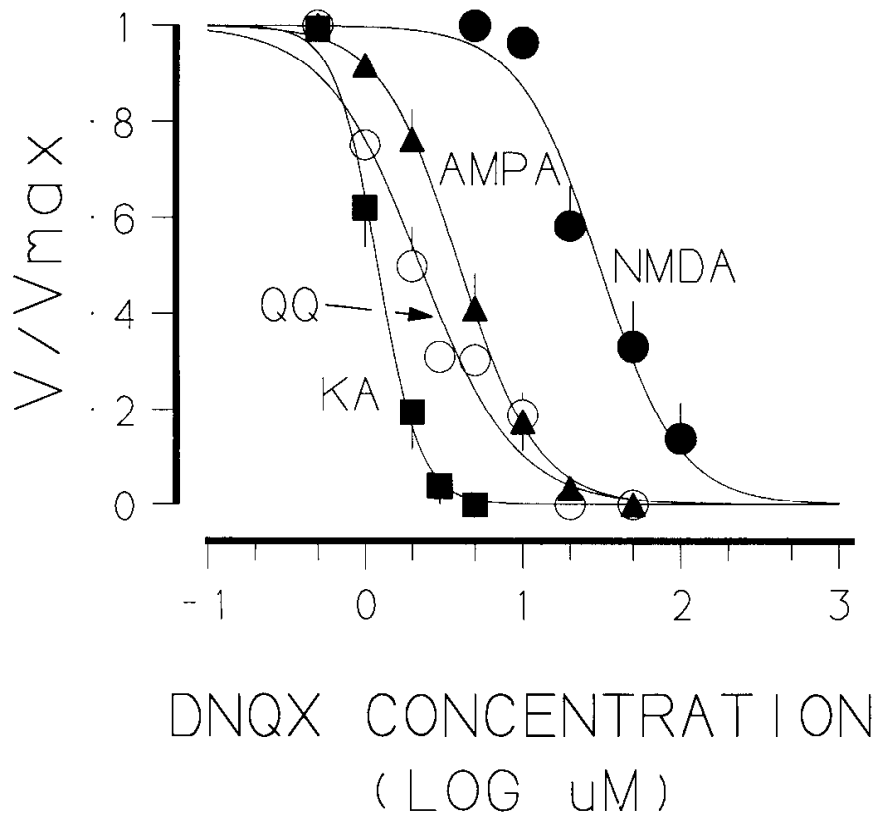

Figure 9. Semilog dose-response curves for KA, QQ, AMPA, and NMDA versus DNQX. The data were derived from experiments such as that shown in Figure 8, where increasing doses of antagonist were tested against fixed submaximal doses of $\mathrm{KA}(15 \mu \mathrm{M})$, QQ $(15 \mu \mathrm{M})$, AMPA $(8 \mu \mathrm{M})$, and NMDA $(300 \mu \mathrm{M})$. The KA and NMDA curves were separated by more than 1 log unit, indicating that DNQX may be used to separate these 2 receptor types. The separation of KA from AMPA and QQ was much less. From these curves, we chose a concentration of $5 \mu \mathrm{M}$ as a working dose for DNQX. At this concentration, KA responses were eliminated, NMDA responses were unaffected, QQ responses were reduced by $70 \%$, and AMPA responses were reduced by $60 \%$. The vertical bars represent SEM. 


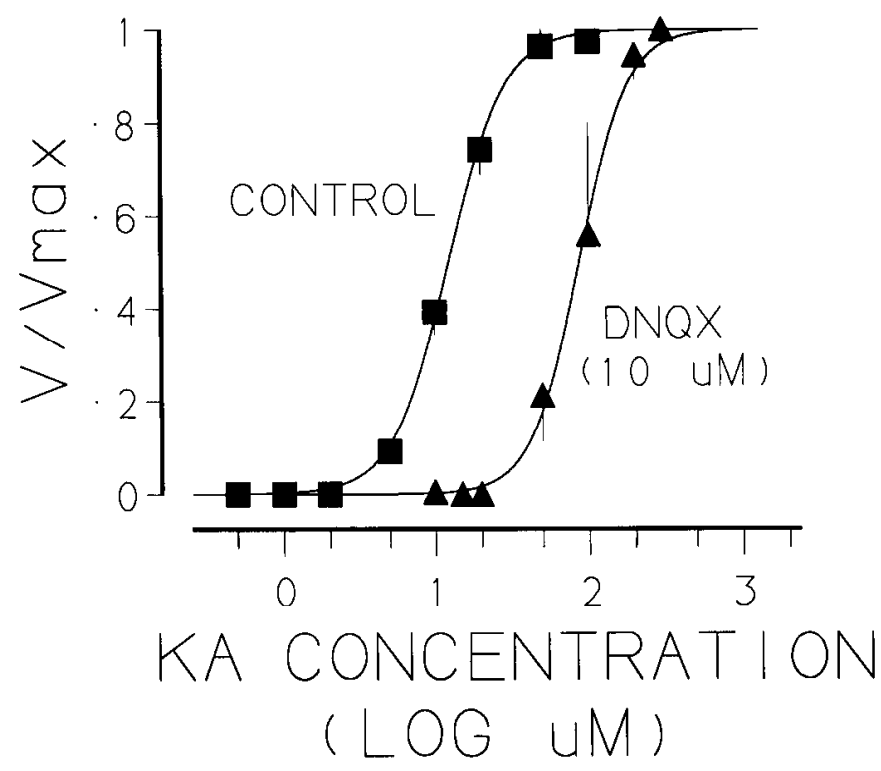

Figure 10. Semilog dose-response curves for KA against fixed dose of DNQX $(10 \mu \mathrm{M})$. DNQX caused a parallel shift in the KA dose-response curve, and $V_{\max }$ was the same in both conditions, approximately $23 \times$ the basal efflux. These results indicate that DNQX is a competitive antagonist at KA receptors in the rabbit retina. The vertical bars represent SEM.

first half shows that $5 \mu \mathrm{M}$ DNQX reversibly abolished the lightevoked release of $\mathrm{ACh}$ from the rabbit retina. During perfusion with $5 \mu \mathrm{M}$ DNQX, the response to light was not discernible from the background noise.

The second part of Figure 11 shows the pharmacological spec- ificity of DNQX. During perfusion with $5 \mu \mathrm{M}$ DNQX, NMDA $(300 \mu \mathrm{M})$ caused a 41 -fold increase in the release of ACh, a large response often seen with the first application of a glutamate agonist. QQ $(15 \mu \mathrm{M})$ elicited a 21 -fold increase in ACh release, but the effect of KA (15 $\mu \mathrm{M})$ was abolished by $5 \mu \mathrm{M}$ DNQX. Because the NMDA response was so large, we took the extra precaution of testing it against a well-described NMDA antagonist. Co-perfusion with DL-2-amino-7-phosphonoheptanoate (DL-AP-7) completely blocked the effect of NMDA, indicating a specific interaction with NMDA receptors. Comparison with the final control peaks shows that, in $5 \mu \mathrm{M}$ DNQX, the NMDA response was not reduced, the QQ response was partially reduced, but the KA response was reversibly abolished. Thus, 5 $\mu \mathrm{M}$ DNQX, which completely blocked the light-evoked release of $\mathrm{ACh}$, was shown to be a relatively specific $\mathrm{KA}$ antagonist in the same experiment. This strongly implies that KA receptors mediate the excitatory input to cholinergic amacrine cells.

\section{Discussion}

By following the release of $\mathrm{ACh}$, we have analyzed the effect of various glutamate analogs and antagonists on the cholinergic amacrine cells of the rabbit retina. Our results lead to 3 major conclusions: (1) The release of $\mathrm{ACh}$ from cholinergic amacrine cells may be stimulated via multiple glutamate receptors, including $K A, Q Q$, and NMDA receptors. (2) Kyn is selective for $\mathrm{KA} \gg \mathrm{QQ}$, while DNQX is selective for $\mathrm{KA}>\mathrm{QQ} \gg \mathrm{NMDA}$. This pharmacological profile is similar to many other systems using glutamate. (3) The light-evoked release of $\mathrm{ACh}$ is blocked by Kyn and DNQX, suggesting that the physiological input to the cholincrgic amacrine cells is mediated via KA receptors. This is consistent with previous work suggesting that bipolar cells release glutamate.
Figure 11. The effect of DNQX on light-evoked release of ACh. Asterisks indicate light stimulation for $4 \mathrm{~min}$ at $3 \mathrm{~Hz}$. In the first half of this experiment, $5 \mu \mathrm{M}$ DNQX (shown by solid bars and dotted lines) reversibly abolished the light-evoked release of $\mathrm{ACh}$. The mean peak: base ratio was 3.7 before and 3.3 after DNQX, but during perfusion with DNQX, the same light stimulation caused no change in release. In the second half of this experiment, we tested the pharmacological specificity of DNQX. Perfusion with DNQX reversibly blocked the KA-evoked release of ACh, but the NMDA response was $40 \times$ and the QQ response was $21 \times$ the basal efflux. Co-perfusion with DL-AP-7 blocked the NMDA response, confirming a specific action at NMDA receptors that was unaffected by DNQX alone. On return to control medium, similar responses were obtained for NMDA, QQ, and KA (peak: base ratios: 20,28 , and 28 , respectively). Comparing the responses in DNQX to the final controls shows that KA was completely blocked, the QQ response was partially reduced, and the NMDA response was unaffected. This indicates that $5 \mu \mathrm{M}$ DNQX, which reversibly abolished the light-evoked release of $\mathrm{ACh}$, is a relatively specific KA antagonist.

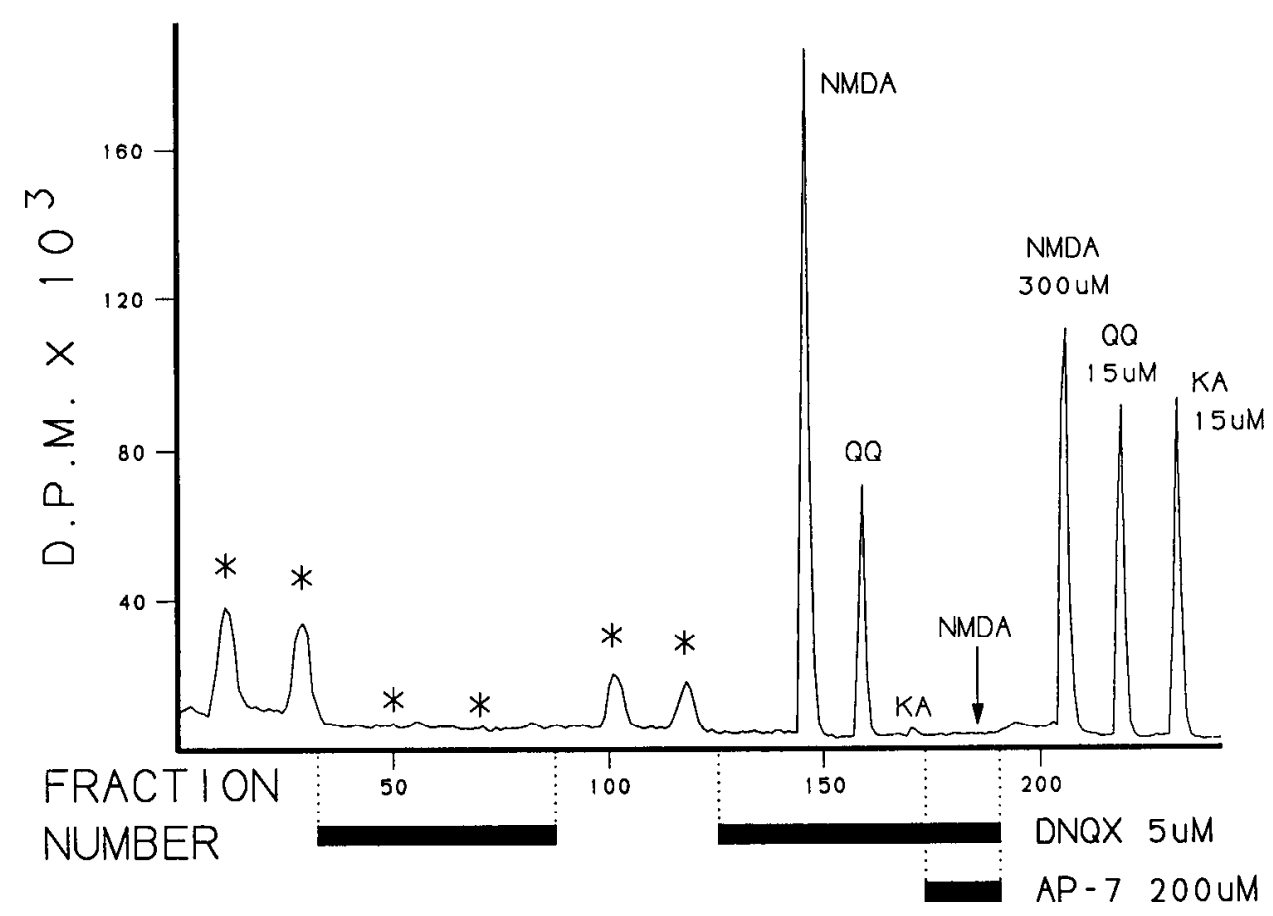




\section{Agonists}

All the glutamate analogs we tested, except NAAG, caused massive $\mathrm{ACh}$ release from the rabbit retina. In fact, these responses were so large, up to $50 \times$ the basal eflux, that cell lysis due to the neural toxicity of these compounds seemed like a possible mechanism for release. However, we used brief applications of submaximal doses and obtained reversible and repeatable responses. Perfusate analysis revealed that only labeled $\mathrm{ACh}$ was released in response to stimulation with $\mathrm{KA}, \mathrm{QQ}$, or NMDA (Fig. 3), and previous work has shown that the cholinergic amacrine cells are the only cells in the retina that synthesize $\mathrm{ACh}$ (Masland and Mills, 1979). Furthermore, ACh release in response to these glutamate analogs was calcium dependent, the hallmark of neuronal release (Fig. 4). These observations indicate that the $\mathrm{ACh}$ release measured in our experiments represents neurotransmitter release from cholinergic neurons and may be taken as a measure of their response.

To demonstrate a direct effect, it is conventional to block synaptic transmission with cobalt and apply the agent in question. In this way, KA, QQ, and NMDA were shown to excite ganglion cells directly in the rabbit retina (Massey and Miller, $1988,1990)$. In this study, we could not use this approach because the dependent measure, $\mathrm{ACh}$ release, is calcium dependent and therefore blocked by cobalt. However, the glutamate analogs may have a direct effect because of the following: (1) Other amacrine cells in the rabbit retina were directly excited by glutamate analogs (Massey and Miller, 1988). (2) The threshold dose for ACh release was lower than the threshold dose for horizontal cells in the outer retina (Massey and Miller, 1987). (3) The effect of glutamate analogs on the ON bipolar cell is sign inverting, so an action at this site would reduce $\mathrm{ACh}$ release, at least in the ON pathway (Shiells et al., 1981; Slaughter and Miller, 1981, 1985). (4) The cholinergic amacrine cells receive direct input from bipolar cells, which are thought to release glutamate (Famiglietti, 1983b; Brandon, 1987; Ehinger et al., 1988; Marc et al., 1989). (5) NMDA, which caused massive ACh release in magnesium-free medium, had almost no effect in the outer retina of the rabbit (Massey and Miller, 1987). Therefore, though we cannot rule out polysynaptic pathways, it is possible that the effect of glutamate agonists on $\mathrm{ACh}$ release is due to a direct effect on cholinergic amacrine cells.

The release of $\mathrm{ACh}$ by glutamate analogs was much greater than the light-evoked release of $\mathrm{ACh}$. At the most, light caused a 10-fold increase in $\mathrm{ACh}$ release at a stimulation rate of $3 \mathrm{~Hz}$ (Massey and Redburn, 1982). The depolarizing transients at light ON or OFF are probably responsible for most of the release of $\mathrm{ACh}$, but they are brief, having a duration of less than 50 msec (Bloomfield and Miller, 1986). There is no such limitation for the exogenous application of glutamate analogs, which are continuously effective while present. Thus, it follows that the response to glutamate analogs should be greater than the lightevoked response. Cunningham and Neal (1985) reported peak: base ratios of 4-5, but only tested concentrations of KA and $\mathrm{QQ}$ in the $1-8-\mu \mathrm{M}$ range. Our results in the low- $\mu \mathrm{M}$ range are comparable, and our larger responses reflect the higher concentrations tested and possibly the continuous perfusion method.

All the effective glutamate analogs, except NMDA, caused $\mathrm{ACh}$ release from the retina in normal physiological medium containing magnesium. NMDA was effective only in magnesium-free medium, as previously reported by Cunningham and Neal (1985). This immediately suggests that NMDA receptors do not carry the physiological input to cholinergic amacrine cells. Furthermore, NMDA antagonists did not block the lightevoked release of ACh (Linn and Massey, 1991). This is quite different from striatal slices, where, in magnesium-free medium, ACh release was mediated by NMDA receptors, and the effect of other glutamate analogs, including $\mathrm{KA}$ and $\mathrm{QQ}$, was negligible (Lehmann and Scatton, 1982; Scatton and Lehmann, 1982). The pharmacology of NMDA-mediated ACh release from the rabbit retina is presented in the following paper (Linn and Massey, 1991).

From the dose-response curves in Figure 2, KA, QQ, and AMPA were almost $3 \log$ units $(1000 \times)$ more potent than glutamate or aspartate. A similar difference has been reported in electrophysiological studies. For example, horizontal cells were depolarized by $10-20 \mathrm{~mm}$ glutamate, but the same response could be obtained with 20-50 $\mu \mathrm{M} \mathrm{KA}$ (Bloomfield and Dowling, 1985a; Massey and Miller, 1987). This difference is probably due to glutamate uptake by glial cells, which effectively prevents the access of exogenous glutamate (Marc and Lam, 1981; Brew and Attwell, 1987; Rosenberg and Aizenman, 1989). Hence, in isolated cells, glutamate and KA are almost equipotent (Lasater and Dowling, 1982; Ariel et al., 1984; Aizenman et al., 1988). In addition, the maximum response with glutamate or aspartate (20-50 mM) was only half that obtained with other glutamate analogs, and the peaks were broader, with slower recovery. These last effects may reflect saturation of the uptake system, but the pharmacological specificity of such high doses is not clear.

AMPA has been proposed as a more selective ligand for the $Q Q$ receptor site because $Q Q$ also activates the metabotropic receptor associated with a second-messenger system (Monaghan et al., 1989). In this study, AMPA was the most potent analog tested, in agreement with previous electrophysiological results in the rabbit retina (Massey and Miller, 1988). Antagonism with Kyn or DNQX produced curves for QQ and AMPA that were close and separated from KA (Figs. 6, 9). This suggests that QQ and AMPA may interact with the same receptor, which is different from the $\mathrm{KA}$ receptor. $\mathrm{KA}$ and $\mathrm{QQ}$ responses were also differentially dependent on calcium. The KA-evoked release of ACh was abolished by low calcium/high magnesium or by cobalt, but the QQ response was only blocked by cobalt in calciumfree medium. These observations suggest that QQ may cause the release of calcium from an internal store or that it may open a calcium channel (Benavides et al., 1988; Murphy and Miller, 1988).

\section{Antagonists}

It was the goal of this study to use glutamate antagonists to identify the excitatory input to the cholinergic amacrine cells. The dose-response curves in Figure 6 show that Kyn is more potent against KA than AMPA and QQ. This is consistent with previous work in the retina and other systems (Coleman et al., 1986; Massey and Miller, 1988; Perouansky and Grantyn, 1989). From the dose-response curves, we chose to use $1 \mathrm{~mm} \mathrm{Kyn,} \mathrm{a}$ dose that eliminated $\mathrm{KA}$ responses but only reduced $\mathrm{QQ}$ and AMPA responses by $50 \%$. At this concentration, Kyn reversibly abolished the light-evoked release of $\mathrm{ACh}$ from the retina. Kyn also blocks NMDA responses, but specific NMDA antagonists did not reduce the light-evoked release of $\mathrm{ACh}$ (Linn and Massey, 1991). These results imply that the physiological input to cholinergic amacrine cells is mediated by $\mathrm{KA}$ receptors. Because ACh release was completely eliminated, indicating that both ON and OFF cholinergic amacrine cells were blocked, it may 
be that both types have the same input, but this idea will require confirmation. In addition, because $\mathrm{ON}$ bipolar cells are not affected by general glutamate antagonists, because they receive input via APB receptors, Kyn must have a post-bipolar-cell effect, at least in the ON pathway (Slaughter and Miller, 1981, 1983c). This suggests that the KA receptors mediating the lightevoked release of $\mathrm{ACh}$ are located in the inner retina.

We also used DNQX, which, in our hands, was a competitive $\mathrm{KA}$ antagonist, $100 \times$ more potent than Kyn. We chose $5 \mu \mathrm{m}$ DNQX as a working dose, and at this concentration, there was no effect on the NMDA-evoked release of ACh (Fig. 8). DNQX has also been reported to interact with the allosteric glycine site of the NMDA receptor complex (Birch et al., 1988), but in the retina, the extracellular concentration of glycine is sufficient to saturate this site (Linn and Massey, 1991). Competition with endogenous glycine may reduce the potency of DNQX at the glycine site, and this may contribute to the selectivity for KA over NMDA receptors.

DNQX $(5 \mu \mathrm{M})$ reversibly abolished the light-evoked release of $\mathrm{ACh}$ from the rabbit retina (Fig. 11). In the same experiment, we showed that the KA-evoked release of $\mathrm{ACh}$ was eliminated by the same concentration of DNQX that blocked the lightevoked response, but the QQ response was only partially reduced, and the NMDA evoked release of $\mathrm{ACh}$ was unchanged. Thus, in agreement with the Kyn results, our observations with DNQX suggest that the physiological input to the cholinergic amacrine cells is mediated by $\mathrm{KA}$ receptors.

Both Kyn and DNQX block the light-evoked release of $\mathrm{ACh}$, and both these antagonists had a preferential effect against KA over QQ. Therefore, it appears that the light-activated receptor fits the profile of the KA receptor. However, the specificity of competitive antagonists such as Kyn and DNQX depends partly on the concentration of agonist, which, for light activation, is unknown. In other words, if the light-evoked release of $\mathrm{ACh}$ were mediated by a low dose of glutamate acting at a QQ receptor, it could be blocked by Kyn and DNQX, leading us to think that a KA receptor was involved. From the data in this study, we can place certain limits on this scenario: Kyn (1 mM) abolished the light-evoked release of $\mathrm{ACh}$ but only reduced the response to $15 \mu \mathrm{M}$ QQ by $40 \%$. Therefore, the light-evoked input must be equivalent to less than $15 \mu \mathrm{M} \mathrm{QQ}$. For the light-evoked response to be completely blocked by Kyn, we estimate that it would have to be equivalent to less than $5 \mu \mathrm{M}$ QQ. From Figures $1 B$ and 2 , the release of $\mathrm{ACh}$ in response to light is almost as large as the response to $5 \mu \mathrm{M}$ QQ and larger than the response to $5 \mu \mathrm{M}$ KA. However, this is the average response to a $3-\mathrm{Hz}$ transient. On a finer time scale, the release of $\mathrm{ACh}$ in response to light must be much greater than $5 \mu \mathrm{M} \mathrm{KA}$ or QQ. Therefore, because responses of this size are blocked by $\mathrm{Kyn}$, we deduce that the light-evoked release of ACh is predominantly mediated by $\mathrm{KA}$ receptors. This is consistent with the similar calcium dependence of the KA and light responses. Finally, the GABA antagonist picrotoxin more than doubles the light-evoked release of ACh (Massey and Redburn, 1982), but it is still blocked by DNQX (not shown), suggesting that QQ receptors only make a minor contribution, at most.

\section{Identity of the bipolar cell transmitter}

Because cholinergic amacrine cells receive direct input from bipolar cells (Famiglietti, 1983b; Brandon, 1987), the release of ACh by glutamate agonists and the blockade of the light-evoked release by glutamate antagonists are consistent with previous work suggesting that the bipolar cell transmitter is a glutamatelike substance. However, a number of candidates have been proposed. NAAG (acetate salt), which at best is a weak NMDA agonist (Westbrook et al., 1986), may be ruled out because it had no effect on $\mathrm{ACh}$ release up to a concentration of $20 \mathrm{~mm}$ in the presence or absence of magnesium. Most recently, some effects of NAAG were shown to be caused by the presence of potassium (Whittemore and Koerner, 1989).

L-Homocysteate has also been proposed as a bipolar cell transmitter (Neal and Cunningham, 1989), but in our hands, L-HCA was mostly an NMDA agonist of moderate potency $\left(\mathrm{ED}_{50}>\right.$ $300 \mu \mathrm{M}$ ) whose effects were reduced by magnesium and DL-AP7. This is consistent with previous work indicating that $\mathrm{L}-\mathrm{HCA}$ is an NMDA agonist in the retina and other systems (Olney et al., 1987; Lehmann et al., 1988). Because the input to cholinergic amacrine cells is not mediated by NMDA receptors, it is unlikely that $\mathrm{L}-\mathrm{HCA}$ is the endogenous transmitter. Furthermore, it is only present in the retina in trace concentrations, less than $1 / 1000$ of the endogenous glutamate concentration (Neal and Cunningham, 1989). The combination of low potency and low concentration make it unlikely that L-HCA could be the transmitter for a population of neurons as numerous as bipolar cells, even the subset that provides input to the cholinergic amacrine cells.

Aspartate is unlikely to be the bipolar cell transmitter because its effects are mediated by NMDA receptors, though even at this site, glutamate is more potent (Olverman et al., 1984). In addition, aspartate is not concentrated in bipolar cells (Marc et al., 1989). Glutamate is the outstanding candidate because bipolar cells are highly immunoreactive for glutamate (Ehinger et al., 1988; Marc et al., 1989), and because it is the only substance known to activate all the different glutamate receptors at high potency. However, in this study, we were consistently unable to block the glutamate-evoked release of ACh with DNQX. One obvious explanation is that glutamate is a mixed agonist, but the glutamate response was not blocked by combinations of DNQX and the NMDA antagonist DL-AP-7. Another more likely possibility is that, at the high concentrations $(5-20 \mathrm{mM})$ required to overcome the glial uptake system, glutamate effects are nonspecific or toxic, leading to secondary effects on retinal neurons. For example, glial uptake of glutamate is electrogenic and associated with potassium release, which may, in turn, stimulate transmitter release in a manner not affected by glutamate antagonists (Barbour et al., 1988). These problems present a strong argument for the use of glutamate analogs, whose potency is not reduced by uptake, to investigate the function of glutamate receptors.

\section{References}

Aizenman E, Frosch MP, Lipton SA (1988) Responses mediated by excitatory amino acid receptors in solitary retinal ganglion cells from rat. J Physiol (Lond) 396:75-91.

Ames A, Nesbett FB (1981) In vitro retina as an experimental model of the central nervous system. J Neurochem 37:867-877.

Ariel M, Lasater EM, Mangel SC, Dowling JE (1984) On the sensitivity of $\mathrm{H} 1$ horizontal cells of the carp retina to glutamate, aspartate and their agonists. Brain Res 295:179-183.

Barbour B, Brew H, Attwell D (1988) Electrogenic glutamate uptake in glial cells is activated by intracellular potassium. Nature 335:433435 .

Benavides J, Claustre Y, Scatton B (1988) L-Glutamate increases internal free calcium levels in synaptoneurosomes from immature rat brain via quisqualate receptors. J Neurosci 8:3607-3615.

Birch PJ, Grossman CJ, Hayes AG (1988) 6,7-Dinitro-quinoxaline2,3-dion and 6-nitro,7-cyano-quinoxaline-2,3-dion antagonise re- 
sponses to NMDA in the rat spinal cord via an action at the strychnine insensitive glycine receptor. Eur J Pharmacol 156:177-180.

Bloomfield S, Dowling JE (1985a) Roles of aspartate and glutamate in synaptic transmission in rabbit retina. I. Outer plexiform layer. J Neurosphysiol 53:699-713.

Bloomfield S, Dowling JE (1985b) Roles of aspartate and glutamate in synaptic transmission in rabbit retina. II. Inner plexiform layer. J Neurophysiol 53:714-725.

Bloomfield S, Miller RF (1986) A functional organization of ON and OFF pathways in the rabbit retina. J Neurosci 6:1-13.

Brandon C (1987) Cholinergic neurons in the rabbit retina: immunocytochemical localization, and relationship to GABAergic and cholinesterase-containing neurons. Brain Res 401:385-391.

Brew H, Attwell D (1987) Electrogenic glutamate uptake is a major current carrier in the membrane of axolotl retinal glial cells. Nature 327:707-709.

Coleman PA, Miller RF (1989) Kainate receptor-mediated synaptic currents in mudpuppy inner retinal neurons reduced by $\mathrm{D}-O$-phosphoserine. J Neurophysiol 62:495-500.

Coleman PA, Massey SC, Miller RF (1986) Kynurenic acid distinguishes kainate and quisqualate receptors in the vertebrate retina. Brain Res 381:172-175.

Copenhagen DR, Jahr CE (1989) Release of endogenous excitatory amino acids from turtle photoreceptors. Nature 341:536-539.

Cunningham JR, Neal MJ (1985) Effect of excitatory amino acids and analogues on ${ }^{3} \mathrm{H}$-acetylcholine release from amacrine cells of the rabbit retina. J Physiol (Lond) 366:47-62.

Ehinger B, Ottersen OP, Storm-Mathisen J, Dowling JE (1988) Bipolar cells in the turtle retina are strongly immunoreactive for glutamate. Proc Natl Acad Sci USA 85:8321-8325.

Famiglietti EV (1983a) On and off pathways through amacrine cells in mammalian retina: the synaptic connections of 'starburst' amacrine cells. Vision Res 23:1265-1279.

Famiglietti EV (1983b) 'Starburst' amacrine cells and cholinergic neurons: mirror-symmetric ON and OFF amacrine cells of rabbit retina. Brain Res 261:138-144.

Foster AC, Fagg GE (1984) Acidic amino acid binding sites in mammalian neuronal membranes: their characteristics and relationship to synaptic receptors. Brain Res Rev 7:103-164.

Honoré T, Davies SN, Drejer J, Fletcher EJ, Jacobsen P, Lodge D, Nielsen FE (1988) Quinoxalinediones: potent competitive nonNMDA glutamate receptor antagonists. Science 241:701-703.

Johnson DA, Pilar G (1980) The release of acetylcholine from postganglion cell bodies in response to depolarization. J Physiol (Lond) 299:605-619.

Lasater EM, Dowling JE (1982) Carp horizontal cells in culture respond selectively to L-glutamate and its agonists. Proc Natl Acad Sci USA 79:936-940.

Lasater EM, Dowling JE, Ripps H (1984) Pharmacological properties of isolated horizontal and bipolar cells from the skate retina. J Neurosci 4:1966-1975.

Lehmann J, Scatton B (1982) Characterization of the excitatory amino acid receptor-mediated release of $\left[{ }^{3} \mathrm{H}\right]$-acetylcholine from rat striatal slices. Brain Res 252:77-89.

Lehmann J, Tsai C, Wood PL (1988) Homocyteic acid as a putative excitatory amino acid neurotransmitter: postsynaptic characteristics at $N$-methyl-D-aspartate-type receptors on striatal cholinergic interneurons. J Neurochem 51:1765-1770.

Linn DM, Massey SC (1991) Acetylcholine release from the rabbit retina mediated by NMDA receptors. J Neurosci 11:123-133.

Lukasiewicz PD, McReynolds JS (1985) Synaptic transmission at the $\mathrm{N}$-methyl-D-aspartate receptors in the proximal retina of the mudpuppy. J Physiol (Lond) 367:99-115.

Marc RE, Lam DMK (1981) Uptake of aspartic and glutamic acid by goldfish photoreceptors. Proc Natl Acad Sci USA 78:7185-7189.

Marc RE, Massey SC, Kalloniatis M, Basinger SF (1989) Immunochemical evidence that the fast neurotransmitter of rods, cones, bipolar and ganglion cells is glutamic acid. Invest Opthalmol Vis Sci [Suppl] 30:320.

Masland $\mathrm{KH}$, Livingstone CJ (1976) Effect of stimulation with light on synthesis and release of acetylcholine by an isolated mammalian retina. J Neurophysiol 39:1210-1219.

Masland RH, Mills JW (1979) Autoradiographic identification of acetylcholine in the rabbit retina. J Cell Biol 83:159-178.

Masland RH, Mills JW, Hayden SA (1984) Acetylcholine-synthesizing amacrine cells: identification and selective staining by using radiography and fluorescent markers. J Neurosci 2:1633-1643.

Massey SC (1990) Cell types using glutamate as a neurotransmitter in the vertebrate retina. Prog Retinal Res 9:399-425.

Massey SC, Miller RF (1987) Excitatory amino acid receptors of rodand cone-driven horizontal cells in the rabbit retina. J Neurophysio $57: 645-659$.

Massey SC, Miller RF (1988) Glutamate receptors of ganglion cells in the rabbit retina: evidence for glutamate as a bipolar cell transmitter. J Physiol (Lond) 405:635-655.

Massey SC, Miller RF (1990) $N$-methyl-D-aspartate receptors of ganglion cells in rabbit retina. J Neurophysiol 63:16-30.

Massey SC, Neal MJ (1979) The light-evoked release of acetylcholine from the rabbit retina in vivo and its inhibition by GABA. J Neurochem 32:1327-1329.

Massey SC, Redburn DA (1982) A tonic gamma-aminobutyric acidmediated inhibition of cholinergic amacrine cells in rabbit retina. $\mathbf{J}$ Neurosci 2:1633-1643.

Mayer ML, Westbrook GL (1987) The physiology of excitatory amino acids in the vertebrate central nervous system. Prog Neurobiol 28: 197-276.

Miller RF, Slaughter MM (1986) Excitatory amino acid receptors in the vertebrate retina: diversity of subtypes and conductance mechanisms. Trends Neurosci 9:211-213.

Monaghan DT, Bridges RJ, Cotman CW (1989) The excitatory amino acid receptors: their classes, pharmacology, and distinct properties in the function of the central nervous system. Annu Rev Pharmacol Toxicol 29:365-402.

Murphy SN, Miller RJ (1988) A glutamate receptor regulates $\mathrm{Ca}^{2+}$ mobilization in hippocampal neurons. Proc Natl Acad Sci USA 85: 8737-8741.

Neal MJ, Cunningham JR (1989) L-Homocysteic acid-a possible bipolar cell transmitter in rabbit retina. Neurosci Lett 102:114-119.

O'Dell TJ, Christensen BN (1989) A voltage-clamp study of isolated stingray horizontal cell non-NMDA excitatory amino acid receptors. J Neurophysiol 61:162-172.

Olney JW, Price MT, Salles KS, Labruyere J, Ryerson R, Mahan K, Frierdich G, Samson L (1987) L-Homocysteic acid: an endogenous excitotoxic ligand of the NMDA receptor. Brain Res Bull 19:597602.

Olverman HJ, Jones AW, Watkins JC (1984) L-Glutamate has higher affinity than other amino acids for $\left[{ }^{3} \mathrm{H}\right]$-D-AP5 binding sites in rat brain membranes. Nature 307:460-462.

O'Malley DM, Masland RH (1989) Co-release of acetylcholine and gamma-aminobutyric acid by a retinal neuron. Proc Natl Acad Sci USA 85:8737-8741.

Perouansky M, Grantyn R (1989) Separation of quisqualate- and kainate-selective glutamate receptors in cultured neurons from the rat superior colliculus. J Neurosci 9:70-80.

Rosenberg PA, Aizenman E (1989) Hundred-fold increase in neuronal vulnerability to glutamate toxicity in astrocyte-poor cultures of rat cerebral cortex. Neurosci Lett 103:162-168.

Scatton B, Lehmann J (1982) $N$-methyl-D-aspartatc-type rcceptors mediate striatal ${ }^{3} \mathrm{H}$-acetylcholine release evoked by excitatory amino acids. 297:422-424.

Shea PA, Aprison MH (1973) An enzymatic method for measuring picomole quantities of acetylcholine and choline in CNS tissue. Anal Biochem 56:165-177.

Shiells RA, Falk G, Nagshingeh S (1981) Action of glutamate and aspartate analogues on rod horizontal and bipolar cells. Nature 294 592-594.

Slaughter MM, Miller RF (1981) 2-Amino-4-phosphonobutyric acid: a new pharmacological tool for retina research. Science 211:182-185.

Slaughter MM, Miller RF (1983a) An excitatory amino acid antagonist blocks cone input to sign-conserving second-order retinal neurons. Science 219:1230-1232.

Slaughter MM, Miller RF (1983b) The role of excitatory amino acid transmitters in the mudpuppy retina: an analysis with kainic acid and $\mathrm{N}$-methyl aspartate. J Neurosci 3:1701-1711.

Slaughter MM, Miller RF (1983c) Bipolar cells in the mudpuppy retina use an excitatory amino acid neurotransmitter. Nature 303:537-538.

Slaughter MM, Miller RF (1985) Characterization of an extended glutamate receptor of the $\mathrm{ON}$ bipolar neuron in the vertebrate retina. J Neurosci 5:224-233.

Tauchi M, Masland RH (1984) The shape and arrangement of the 
cholinergic neurons in the rabbit retina. Proc R Soc Lond [Biol] 223: 101-119.

Tauchi M, Masland RH (1985) Local order among the dendrities of an amacrine cell population. J Neurosci 5:2494-2501.

Vaney DI (1984) 'Coronate' amacrine cells in the rabbit retina have the 'starburst' dendritic morphology. Proc R Soc Lond [Biol] 220: 501-508.

Westbrook GL, Mayer ML, Namboordiri MAA, Neale JH (1986) High concentrations of $N$-acetylaspartylglutamate (NAAG) selectively ac- tivate NMDA receptors on mouse spinal cord neurons in cell culture. J Neurosci 6:3385-3392.

Whittemore ER, Koerner JF (1989) An explanation for the purported excitation of piriform cortical neurons by $N$-acetyl-L-aspartyl-L-glutamic acid (NAAG). Proc Natl Acad Sci USA 86:9602-9605.

Yamada KA, Dubinsky JM; Rothman SM (1989) Quantitative physiological characterization of a quinoxalinedione non-NMDA receptor antagonist. J Neurosci 9:3230-3236. 